tiques. American Political Science Review, Vol. 82, No. 3, pp. 853-901.

Bell, Daniel. Summer 1977. The Future World Disorder: The Structural Context of Crises. Foreign Policy, Vol. 27, pp. 109-135.

Benn, Anthony Wedgwood. December 1971. The Impact of Technology on the Structure of Government. Bulletin of Atomic Scientists, Vol. 27, pp. 23-26.

Bentley, Arthur F. 1908. The Process of Government, A Study of Social Pressures. Chicago; reissued Bloomington: Chicago University Press, 1949.

Boulding, Kenneth. 1989. Three Faces of Power. London: Sage Publications.

Boyer, William W. Second Quarter 1986. Management of Macrotransition. Technocracy Digest, Vancouver, No. 280, pp. 12-15.

Bureau of Executive Manpower, United States Civil Service Commission. November 1969. Characteristics of the Federal Executive. Washington, D.C.: U.S. Government Printing Office, 19pp.

Chase, Stuart. 1948. The Proper Study of Mankind: An Inquiry into the Science of Human Relations. New York: Harper \& Brothers.

Cleveland, Harlan. October 21, 1980. Educa- tion for the Macrotransition We Are In. Keynote Address at the Annual Meeting of the National Association of Schools of Public Affairs and Administration. San Antonio, 16pp.

Cleveland, Harlan. 1985. The Knowledge Executive: Leadership in an Information Society. New York: E. P. Dutton.

Evans, Peter B., Dietrich Rueschemeyer, and Theda Skocpol, eds. 1985. Bringing the State Back In. New York: Cambridge University Press.

Henderson, Hazel. October 1985. Posteconomic Policies for Postindustrial Societies. ReVision Magazine, as quoted in William W. Boyer, Needed: A New Partnership. Chemtech, Vol. 15, No. 10, pp. 582-584.

Kingston, Robert J., ed. 1988. Perestroika Papers. Dubuque, Iowa: Kendall/Hunt Publishing Co.

Mosher, Frederick C. 1968. Democracy and the Public Service. New York: Oxford University Press.

Price, Don K. 1965. The Scientific Estate. New York: Oxford University Press.

Robson, William A. 1954. The University Teaching of Social Sciences: Political Science. Paris: UNESCO.
United Nations Center on Transnational Corporations. 1988. Transnational Corporations in World Development, Trends and Prospects. New York: United Nations.

Waldo, Dwight. 1981. The Enterprise of Public Administration, A Summary View. Novato, Calif.: Chandler and Sharp.

World Commission on Environment and Development. 1987. Our Common Future. Oxford: Oxford University Press.

\section{About the Author}

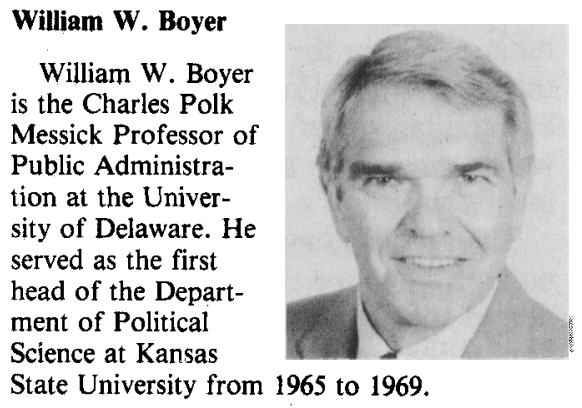

\title{
More About Applied Political Science
}

\author{
Harry Eckstein, University of California, Irvine
}

In a recent issue of $P S$ (XXII, 3, September 1989, 635-639), Gary Andres and Janice Beecher call for something that seems obviously desirable but, as they themselves point out, is not easy to achieve: bridging the gap between academic political science and practical politics. Some of their arguments seem to me welltaken. But I write this response because of what they omit and distort. That is most of what really matters in dealing with this seemingly simple, but very complex, matter. Their views, as is often the case with the "obvious," are simplistic, despite the existence of literature that wrestles with the complexities.

First, though, the good points. Andres and Beecher point out that political scientists are not sufficiently used in practical politics, public and private. They exaggerate this point a bit, and they do not mention any misuse of academics by politicians (see below); but they seem to me basically to be right. They write even more to the point about the lack of sufficient flow from practical politics to academic political science; political scientists who go into practical work are, granted a few exceptions, not given proper credit for it when they wish to return to the academy. Andres and Beecher surely are also right in calling for a predictive political science. In principle, theories that can explain (I assume that they mean "scientifically" explain, in Hempel's sense) also can predict; but actual prediction unfortunately is not common in our field, even for its crucial academic use: testing theory. And their vision of the integration of academic and practical political science surely is a laudable vision, anyway at first glance.

I hope, and assume, that they do not consider their vision new. It goes back about as far as political study itself; in fact, the separation of academic study and worldly activity is of quite recent origin. If only for that reason, periodic exhortations to mobilize political scientists for practical work in the "real world" are probably worthwhile. I did once write (in reply to Leo Strauss' accu- sation that political scientists are fiddling while Rome burns, without realizing that Rome is burning and they are fiddling) that political mobilization of the profession was hardly needed at the time, and gave a very long paragraph's worth of still pertinent reasons (Eckstein, 1967). Still, as Ernest Lynton argued persuasively in a recent book, higher education in general nowadays falls far short of fulfilling an ancient, critical social function: training capable, needed personnel (as the ancient universities emphasized the training of clergymen and scribes) and, especially important in this age of rapid accumulation and change of knowledge, retraining people in midcareer. Among the sinners in regard to this, political science departments surely rank high.

The situation is not, however, as bleak as Andres and Beecher depict it. Note the spread of courses on practical public morality, the mushroom growth of Schools of Public Affairs, the vogue of policy studies (since Lasswell), and the 
appearance, in Schools of Public Affairs at any rate, of "mid-career fellows." Nor is the problem, such as it is, one-sidedly the fault of "ivorytower" academics. The men of affairs too often think that they have nothing to learn from those in the academy, or only from certain types of them (e.g., from the "dismal scientists"). Even if they use academics, they too often ignore them, or else recruit only people who are, so to speak, pseudo-academics in search of political careers or people willing to say what the practitioners want to hear.

Here lies the first difficulty Andres and Beecher overlook: Who in the practical political world will listen to academic ideas, and to what will they listen? I write from personal disillusion, as a consultant on insurgency in a Government Department and two agencies, during the Vietnam War, from 1962 to 1966 (when I stopped, wearied by the physical strain involved in working in two worlds and repelled by our policies).

By that time, quite a bit of academic knowledge pertinent to insurgency had been developed. Some of it originated in the literary reflections French officers made thoughtful by their experiences in Indo-China; some in the academy, as in Princeton's Internal War Prospect, which I directed. We also had Clausewitz, T. E. Lawrence, Mao, and Giap in our libraries. Although our understanding of insurgency was, and still is, painfully limited, it would have sufficed to prevent some of our more egregious policy errors in regard to it.

Experience in Washington was useful to me for the glimpses of "realworld" politics it yielded. But it also indicated: (1) that political scientists in governmental positions were a special breed that resembled rather than complemented the men of affairs; (2) that academic ideas tended to be filed away, in a sort of reflexive manner, rather than being taken seriously - at any rate, if they did not fit the practical people's preconceptions; (3) that officials interacted with academics mainly to convince them (in this case, that we were winning) and to get their support, in the guise of seeking guidance; and (4), as it seems to me now, that the departments were playing a sort of game- "our" consultants (numbers, reputation) versus "yours"-for the sake of influence higher up. The small number of ideas that did eventually filter through to the "politicians" (including bureaucrats) seems, in retrospect, to have come more from research than from the researchers.

A second difficulty comes from us: What do we say to the practical men? Do we have enough "usable knowledge," to use Lindblom and Cohen's label (1979), to make much difference to policy decisionsassuming that it will be taken seriously? (I emphasize that the questions pertain to decisions, rather than to what Lindblom always stressed: "policy evaluation" [1963].) Surely we do have some usable knowledge,

\section{Who in the practical political world will listen to academic ideas, and to what will they listen?}

and some of it actually is applied in the "real world"-for instance, to help devise electoral strategies or for redistricting. In many areas, however, our knowledge is too embryonic, or beside the point, to be applied, except as quackery; and these areas too often are precisely the ones in which political men seek academic guidance-usually after some unforeseen disaster. Since the wholly unexpected fall of the Shah, for instance, both the government and some multinational corporations have sought out academics to provide improved political forecasting models. Much, after all, is at stake for them. But we have only limited and conflicting knowledge about the conditions of political stability and instability. And forecasting the fall of a ruler or government falls in the same category as forecasting earthquakes: the events are "catastrophes"-in the technical sense of discontinuous, sporadic events-which can be explained after the fact, but not forecast with reasonable accuracy.

Much the most bothersome issue, however, is a third: whether the close identification of political inquirers and political practitioners, and much two-way traffic between the worlds of political inquiry and action, is in fact as desirable as it may seem at first glance. Surely even Andres and Beecher do not want the total confusion of the roles. Nor does anyone want their absolute separation. But where draw the line? This is the issue Max Weber faced in his lectures "Politics as a Vocation" and "Science as a Vocation" (1946), after a lifetime of working in both spheres; so have some contemporary "policy scientists," most notably Lindblom.

I took up this issue in a paper, subsequently published (1967), before a plenary session of the American Political Science Association, both expounding Weber's views and trying to build on them. I want to summarize here only two points made in the paper: that the roles of "politicians" and "political scientists" involve very different "cultures" (or, as Husserl called them, "life-worlds") and that too much blurring of their spheres entails dangers to both of them.

In regard to the academics' and politicians' cultures, I argue (148-51) the following:

1. The two "life-worlds" call for quite different feelings in regard to the work done in them. The essential business of governing is making choices, for which one needs, or needs to develop, passionate convictions and a sense of certainty-in the manner of physicians and for similar reasons. Social Science, per contra, is morally (even if not evaluatively) silent and studiously tentative. It also breeds a strong sense of fallibility-of doubt, skepticism, and being critical of one's own work.

2. The contexts toward which work in the roles is directed also are opposites. Policy decisions must willy-nilly be taken with reference to concrete, extremely complex wholes. Academics, to the contrary, work with abstract and simplified aspects of whole experience. The division of labor in the practical world is one of substantive tasks, each of which is itself complex; in academic inquiry it 
involves splitting the concrete into fragments (psychological, economic, administrative, etc.).

3. Work in the two realms involves different organizational frameworks. Political work, for instance, is typically done in large, routinized organizations. Academic inquiry, although becoming more bureaucratized, still is mostly done individually, with few prescribed routines.

4. Time and space involve different dimensions in the two cultures. Political space is tied, in the main, to particular societies; scientific space is ecumenical. Political time is inherently short; action usually must be expeditious, whether or not all the returns are in. The academic may sit long and patiently (even now, despite the overemphasis on rapid "productivity"), thinking, calculating, or awaiting inspiration.

All this, to repeat, is only a summary of a rather elaborate argument and rationale. It should suffice to help explain why the two roles, ideally complementary precisely because of their differences, often only lead to misunderstanding, even contempt, in interaction. It should also help explain why the practical men largely seek out their own kind in the academy, and vice versa, when the opposite would be much more useful.

As for the dangers: Weber pointed out that the chief peril of confusing the two life-worlds to social scientists is the temptation to play at being moral teachers, agitators, demagogues, and "prophets" in the academy-something that can, of course, also occur through dissident "engagement." This is a danger, granted, only if one agreed with Weber on the limits of science (its inability to provide "correct" values and to infuse "meaning" into life, and its inability to yield final, definitive Truth) and with his perception of its peculiar dignity as an activity, which lies precisely in the taxing labors scientists perform despite these limits.

In the case of politicians the chief peril is what Weber called "scientism." That meant two things to him. One is turning a scientific theory into a moral imperative, which compromises both theory and morality. The second involves "politicians" more directly. The need for choice often is pressing in the "real world" and choices often are difficult to make. If so, the practical men may thus become only too susceptible to the scientists, abdicating to them the responsibilities intrinsic to their roles. Actually, both types of men may thus become unfaithful to their responsibilities if their roles are confused: in one case, to inquire; in the other, to choose.

There is more to be said about all this-much more. Suffice it to say here that, though exhortations to do "applied political science" may be salutary as an antidote to too strict separation, we need much more the careful, subtle analysis of desirable linkages of, and division between, the roles, in the manner of Weber's lectures-splendid lectures, but certainly not the last words on the subject.

\section{References}

Braybrooke, David and Charles E. Lindblom. 1963. A Strategy of Decision: Policy Evaluation as a Social Process. New York: Free Press.

Eckstein, Harry. 1967. "Political Science and Public Policy." In Ithiel de Sola Pool, ed., Contemporary Political Science. New York: McGraw-Hill.

Lindblom, Charles E. and David K. Cohen. 1979. Usable Knowledge: Social Science and Social Problem Solving. New Haven: Yale University Press.

Weber, Max. 1946. From Max Weber: Essays in Sociology. H. H. Gerth and C. Wright Mills, transl. and eds. New York: Oxford.

\title{
Whither the Political Science Major at Liberal Arts Colleges?
}

\author{
Timothy V. Kaufman-Osborn, Whitman College
}

Note: The following remarks were delivered at a roundtable conducted under the auspices of the American Political Science Association at its 1989 annual meeting in Atlanta. The session was titled "Re-thinking the Political Science Major at Liberal Arts Colleges." Other participants included Joan Tronto, Hunter College; Raymond Seidelman, Sarah Lawrence College; and Timothy Cook, Williams College. The views expressed here are my own and do not necessarily reflect those of my colleagues in the Department of Politics at Whitman College.

The liberal arts college at which I teach is distinguished chiefly by the obscurity of its location in Walla Walla, Washington. Assuming my position at Whitman College in 1982, I inherited a conventional political science major. Courses were divided into four subfields: American politics, political theory, international relations, and comparative politics. Students who elected to complete this major were required to enroll in at least one introductory course in each of these areas; and, as seniors, all were subjected to written examinations on three of the four as well as a more comprehensive oral examination.

At the time, this program seemed familiar and unobjectionable. On the whole, its form recapitulated that of the graduate program I had just completed as well as that of the APSA Personnel Newsletter. As the years passed, however, concerns about the adequacy of this structure became ever more pressing. My first intimation that something was amiss emerged when, as chair of the department, I found it necessary to determine the appropriate subfield designation for new courses titled "Politics and Literature" and "Politics and Film." These administrative inconveniences blossomed into outright anomalies when, in response to personnel changes, our courses in law came to be taught primarily by a political theorist rather than by an Americanist. Did this mean that this area was now to be accorded a new subfield location? Moreover, what was I to do with courses, like those in political economy, which seemed to escape altogether the tidy confines of our 